\title{
Insilico docking studies of daidzeion compounds as selective estrogen receptor modulator (SERMS) breast cancer
}

\author{
Yani Suryani ${ }^{1, *}$, Opik Taupiqurrohman ${ }^{1}, A i$ Rikani $^{1}$, and Epa Paujiah $^{2}$ \\ ${ }^{1}$ UIN Sunan Gunung Djati Bandung, Department of Biology, 40614, West Java, Indonesia \\ ${ }^{2}$ UIN Sunan Gunung Djati Bandung, Department of Biology Education, Bandung 40614, West Java, Indonesia
}

\begin{abstract}
The aims of this study to analyze the potential of daidzein compounds as selective estrogen receptor modulators (SERMs) compared with $17-\beta$ estradiol. SERMs is a compound that can be used as a anticancer of breast cancer. The process of analysis is done computation, that is molecular docking. The research was conducted at Data Processing Laboratory of Department of Biology Faculty of Science and Technology, State Islamic University of Sunan Gunung Djati Bandung in December 2017 until February 2018. The result of analysis showed that daidzein compounds have excellent potential as SERMs. This is indicated by the very low energy value of binding affinity of Deidzein $(-9.4 \mathrm{kcal} / \mathrm{mol})$ compared to $17-\beta$ estradiol $(-8.9 \mathrm{kcal} / \mathrm{mol})$. The smallest of energy binding affinity value indicates a very high binding ability.
\end{abstract}

\section{Introduction}

Breast cancer is a disease with the highest mortality rate, an Indonesian women. There were approximately 48,998 cases occurring with a mortality rate of $21.4 \%$ [1]. Factors that play an important role in the development of breast cancer are estrogen and estrogen alpha receptors [2]. RE- $\alpha$ is responsible for controlling transcription of nuclear DNA that is considered an important component of breast cancer signal network and appears as a novel biomarker of this disease [3].

Treatment strategies are largely focused on blocking signals passing through RE- $\alpha$ [4]. Clinical therapy has been using drugs that act as SERMs (Selective Estrogen Receptor Modulators). SERMs compounds are compounds capable of competing with endogenous estrogens to modulate the activity of estrogen receptors [5]. Types of SERMs that have been known and used in clinical use include tamoxifen and raloxifen that act directly as ER- $\alpha$ antagonists [6]. But in its use cause various side effects such as cataracts, stroke, uterine cancer and blood clots [7]. An approach taken to limit the side effects of treatment therapy is by using drugs that can work as SERMs and are sourced from natural ingredients.

One type of drug candidate that is predicted to act as a SERMs compound is daidzein (7,4'-dihydroxy isoflavones). Daidzein belong to phytoestrogens and potentially become a compound anticancer breast, daidzein found in soybean [8]. Previous in vitro studies have shown that daidzein is able to inhibit the proliferation of MCF-7 breast cancer cell cultures, and is associated with expression of estrogen alpha receptors
(RE- $\alpha)$ [9]. Based on epidemiological studies, consumption of soy isoflavones especially daidzein has a compreventive benefit to breast cancer [10].

The present study focused on silico analysis of daidzein to confirm, evaluate, and learn more about daidzein's ability as a ligand in RE-a. This study was conducted by tethering daidzein molecules to RE- $\alpha$. Insilico testing is used as a connection between one stage to the next with a short time, accurate results and low cost to determine the effectiveness of the compound [11]. The purpose of this study is to determine the ability of daidzein as a competitor and how daidzein conformation on RE- $\alpha$ in silico.

\section{Material and Methods}

Three-dimensional Receptor Estrogen (RE)- $\alpha$ structure downloaded from the Protein Data Bank website (GDP, coded 1SJ0) and a three-dimensional structure of daidzein compound downloaded from zinc.docking.org with the zinc code: 18847034 and 17- $\beta$ Estradiol with zinc code: 13520815 .

The device used is the ASUS A43S series laptop hardware with Intel Core i3-2350 M @2.30 GHz processor and Windows 7 ultimate 32-bit operating system. Then the software used for molecular docking is Accelrys Discovery Studio 4.5 for material preparation and conformational visualization between small molecules and macromolecule systems, PyRx (Virtual screening tool) for molecular tethering. Here are the stepsn

1. Preparation: The complex structure of RE- $\alpha$ GDP (1SJ0) opens on the Accelrys D.S 4.5 software then

\footnotetext{
*Corresponding author: yan_dhika@yahoo.com
} 
between receptors and separated crystallographic ligands.

2. Validation Method: At this step the optimization of RE- $\alpha$ by determining the grid box binding site (binding site) using AutoDock Vina-PyRx software with Grid Center $\mathrm{x}=31,6846, \mathrm{y}=-1,1900$ and $\mathrm{z}=$ 25,3418 which has dimension $25 \times 25 \times 25 \AA$, Subsequently a recombination of receptor and crystallographic ligands is performed. It then divides the poses to compare the location of the crystallographic ligand and the result of retouching on the receptor using Accelrys D. S. 4.5 software. Validation parameters include RMSD $<2 \AA$. The smaller RMSD shows the position of the retarded ligand which is closer to the position of the crystallographic ligand [12].

3. Molecular Mooring Simulation: Molecular tethering is done with the Pyrenx assisted Vina AutoDock program. Macromolecule and ligand files are then opened in this program. Macromolecule and ligand files in * .pdb format are then converted into * .pdbqt format via the PyRx assisted Vina AutoDock program. The .pdb format in the ligand and receptor shows no charge on the molecule, whereas the .pdbqt format shows a partial charge on each atom [13]. Then tethered using a Grid box determined by the position of the crystallographic ligand on the alpha estrogen receptor binding site at the validation stage. The result of this tethering will result in the affinity binding value of each tested ligand. The parameters used are the lowest affinity binding values of each ligand which will proceed to the next stage of conformational visualization.

4. Visualization of Conformation: The conformational visualization is performed on the Accelrys D. S. 4.5 device by opening the receptor structure as a macromolecule which is then tethered with each of the lowest energy ligands to see the conformation and interaction with the amino acid residues formed.

5. Data Analysis: The simulation results of molecular tethering were analyzed for conformation and interaction using Accelrys D. S. 4.5 software taking into account the types of interactions and amino acid residues involved.

\section{Result and Discussion}

The daizein tethering process carried out against a receptor protein in the form of the RE- $\alpha$ complex with the $1 \mathrm{SJ} 0$ code, chosen for being validated by the GDP site as a non-mutant receptor with a resolution $<2 \AA$. The result of the preparation is the lumbar receptor beam by removing the water group. Prior to molecular tethering, a method validation is performed. This stage aims to determine the validity of the software and determine the boundaries of the search area of the ligand binding site on RE- $\alpha$. The parameters used are RMSD and affinity binding, RMSD $<2 \AA$ and affinity binding values are parameters to maximize software work for the next step [11]. Validation of molecular tethering is done by recombination using Pyrenx-assisted AutoDock Vina. Validation was performed on the active side of the cocrystal ligand to the crystallographic ligand. The result of validation method can be seen in Table 1 .

Table 1. Results of Crystallographic and Co-Crystal Ligand Recovery Against RE- $\alpha$.

\begin{tabular}{|c|c|c|c|}
\hline \multirow[b]{2}{*}{ No. } & \multirow[b]{2}{*}{ Ligand } & \multicolumn{2}{|c|}{ Tethered Result } \\
\hline & & $\begin{array}{c}\text { Binding Affinity } \\
\text { (kckal/mol) }\end{array}$ & $\begin{array}{c}\text { RMSD } \\
\text { (§̊) }\end{array}$ \\
\hline 1. & Crystallographic & $-11,3$ & - \\
\hline 2. & $\begin{array}{l}\text { Result of } \mathrm{Co}- \\
\text { Crystal tethered }\end{array}$ & $-11,3$ & 1,38 \\
\hline
\end{tabular}

Table 1 shows the RMSD value of the recombinant ligand that is $1.38 \AA$, meaning the value is less than $2 \AA$. This value implies that tethering can be accepted because the value is still $<2 \AA$, the smaller the deviation value, the more accurate the calculation [11]. The affiinity binding value of the crystallographic ligand and the result of tethering have the same value of $-11.3 \mathrm{kcal} /$ mol, meaning no change in the value of binding affinity. Meanwhile, the poses of the crystallographic ligand and the results of the tethering are visualized by the Fig. 1.

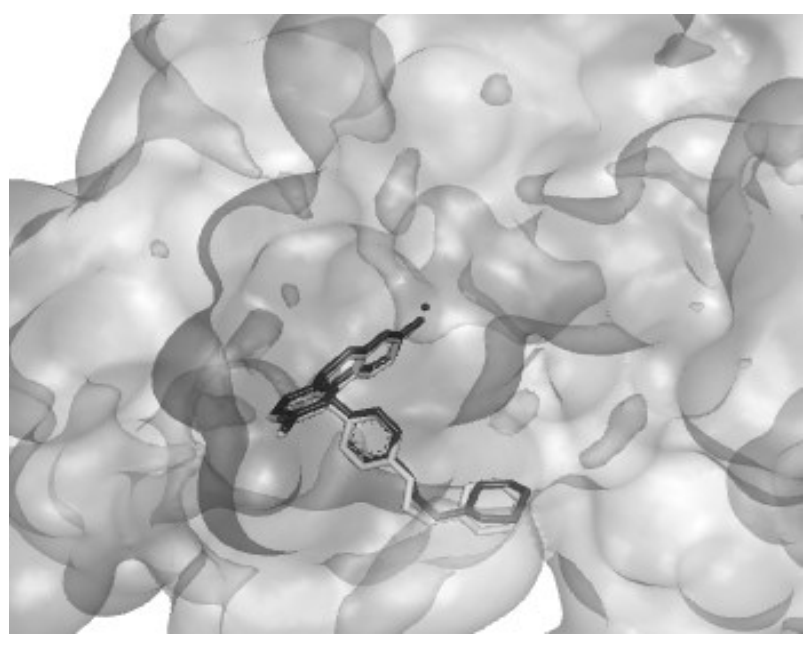

Fig. 1. Results of tethered crystallographic ligands (yellow) Compared to Co-Crystal Ligands Optimized Results (red) Using Accelrys Software D.S 4.5.

Fig. 1 shows the position of the crystallographic ligand and the recovered ligand residing on the same active side of RE- $\alpha$. This means that the positions of atoms in the recovered ligand do not differ greatly with the position on the crystallographic ligands $[14,15]$. These results indicate that $1 \mathrm{SJ} 0$ receptors can be used for further tethering.

Furthermore, a daidzein tethering simulation was performed as a ligand candidate on alpha estrogen receptor using a predefined grid box on the validation result. The more stable the interaction of the ligand with the protein is seen with the lower free energy shown by 
the affinity binding value. Here are the lowest free energy results obtained from tethering:

Table 2. Comparison of Affinity Balance Value (kcal/mol) Daidzein and 17- $\beta$ Estradiol.

\begin{tabular}{|c|l|c|}
\hline No & \multicolumn{1}{|c|}{ Ligan Name } & Binding Affnity (kkal/mol) \\
\hline 1. & Daidzein & $-9,4$ \\
\hline 2. & $17-\beta$ Estradiol & $-8,9$ \\
\hline
\end{tabular}

Table 2 shows the affinity binding value of daidzein compound ie $-9.4 \mathrm{kcal} / \mathrm{mol}$ lower than endogenous ligand (17- $\beta$ Estradiol) $-8.9 \mathrm{kcal} / \mathrm{mol}$. Lower affinity binding values indicate that the ligand may interact spontaneously with ER- $\alpha$ without requiring large bonding energies to bind, so that the ligand is suspected to have an estrogenic potential [11]. With lower affinity binding values than the control ligand predicted daidzein is able to inhibit the process of receiving signals at estrogen alpha receptors.

The lowest affinity binding values of daidzein and control ligand were then visualized in conformation to estrogen alpha receptors. The results of daidzein conformation and $17-\beta$-estradiol RE- $\alpha$ can see at Fig. 2.

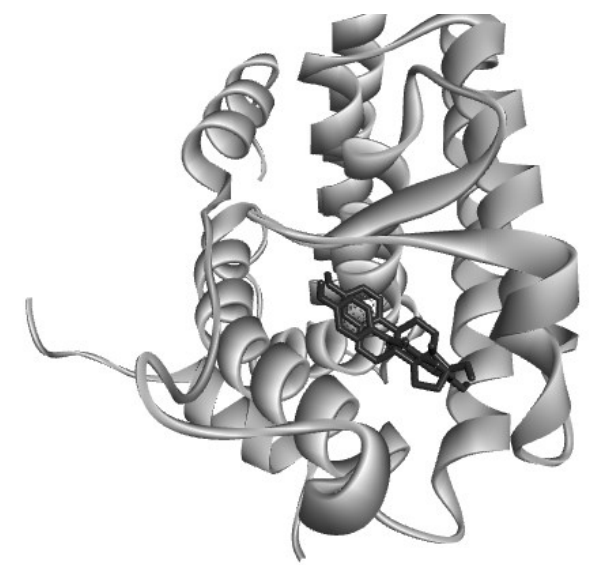

Fig. 2. Molecular Interactions between Daidzein Compounds (purple color), and 17- $\beta$ Estradiol (red color) with Estrogen Alfa Receptor.

The conformational analysis of Fig. 2 shows that the daidzein ligand and 17- $\beta$ Estradiol are on the same active RE- $\alpha$ side. Thus daidzein compounds are predicted to have the ability to block the action of signaling from endogenous ligands to estrogen alpha receptors. Further interaction analysis results are done by taking into account the non-bond interaction consisting of hydrogen bonding, hydrophobic interaction and electrostatic interaction. The types of interactions that occur between daidzein and RE- $\alpha$ can be seen in Fig. 3.

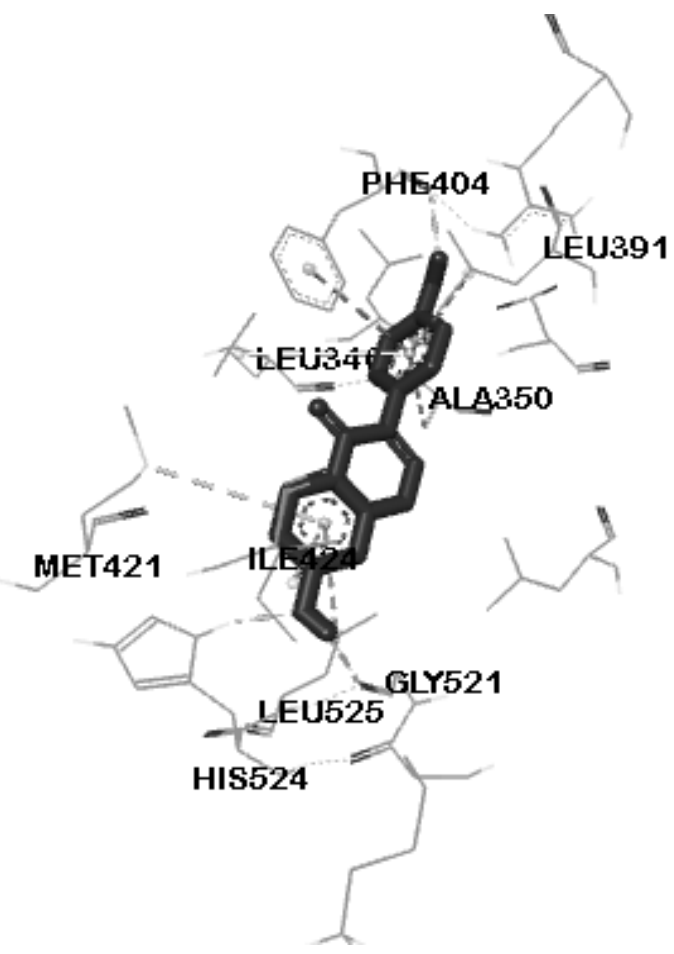

Fig. 3. Amino Acid Residue Interactions Tied to Daidzein Compounds on RE- $\alpha$.

Fig. 3 shows the conformation of daidzein residing on the binding site of RE- $\alpha$ with the amino acid residues involved. The types of amino acid residues involved are PHE404, LEU391, ALA350, ILE424, GLY521, LEU525, HIS524, MET421 and LEU346. These amino acid residues are taken into account in determining the type of interaction to be formed. The types of interactions are presented in Table 3.

Table 3 shows the molecular interaction of daidzein to $\mathrm{RE}-\alpha$ in the $5 \AA$ range range. It is predicted that there are 3 hydrogen bonds and 7 hydrophobic interactions (Table 3). The amino acid residues involved in forming conventional hydrogen bonds formed between daidzein and RE- $\alpha$ are HIS524, PHE404 and GLY521 with a spacing of $2.13 \AA, 2.32 \AA$ and $2.37 \AA$ respectively. Then the hydrophobic interactions involving Pi-alkyl groups formed between daidzein and RE- $\alpha$ residues are ALA350, ILE424, LEU525, LEU391 and LEU346 with a spacing of $4.78 \AA, 4.82 \AA, 5.02 \AA, 5.20 \AA$ and $5.23 \AA$. Other interactions involving $\mathrm{Pi}-\mathrm{Pi}$ and $\mathrm{Pi}$-Sulfur are formed by PHE404 residues at a distance of $4.71 \AA$ and MET421 at a distance of $5.12 \AA$. The amount of hydrogen bonding and hydrophobic interaction involved and the distance from the bonds that will affect the value of free energy, the more interaction and closer the bonding distance that occurs in molecular tethering the lower the value of free energy obtained and vice versa. The low distance interval and strong effect on free energy for molecular blocking is between 2.5 - $3 \AA$ [11]. 
Table 3. Non-Bond Interaction between Daidzein and Estrogen Alfa Receptor (RE- $\alpha)$.

\begin{tabular}{|c|c|c|}
\hline $\begin{array}{c}\text { Amino Acid } \\
\text { Residues }\end{array}$ & $\begin{array}{c}\text { Distance } \\
(\mathbf{\AA})\end{array}$ & Type of Interaction \\
\hline HIS524 & 2,13 & Hydrogen Bond \\
\hline PHE404 & 2,32 & Hydrogen Bond \\
\hline GLY521 & 2,37 & Hydrogen Bond \\
\hline PHE404 & 4,71 & Hydrophobic \\
\hline ALA350 & 4,78 & Hydrophobic \\
\hline ILE424 & 4,82 & Hydrophobic \\
\hline LEU525 & 5,02 & Hydrophobic \\
\hline MET421 & 5,12 & Etc. \\
\hline LEU391 & 5,20 & Hydrophobic \\
\hline LEU346 & 5,23 & Hydrophobic \\
\hline
\end{tabular}

The hydrogen bond is a molecular bond between $\mathrm{H}$ atoms with an electronegative atom such as $\mathrm{N}, \mathrm{O}$ and $\mathrm{F}$. The role of hydrogen bonds is very significant in the structure of proteins because the structural stability of a protein is influenced by hydrogen bonds. While the residue involved in hydrophobic interaction is a residue of nonpolar amino acid. The hydrophobic effect is usually defined as a reduction in one of the relatively unfavorable interactions that occur between water and nonpolar atoms [16]. Further conformational analysis between 17- $\beta$ Estradiol with RE- $\alpha$ can be seen in Fig. 4.

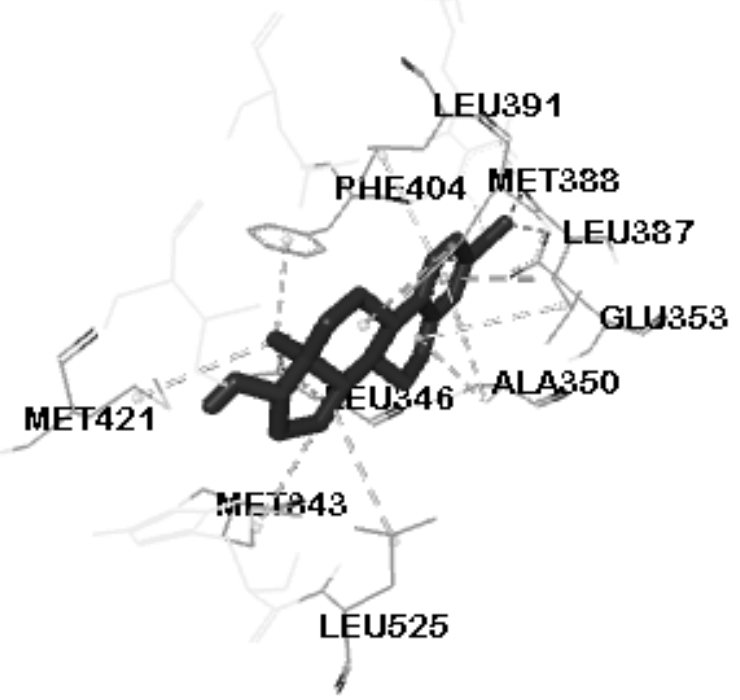

Fig. 4. Amino Acid Residue Interactions Tied to 17- $\beta$ Estradiol Compounds on RE- $\alpha$.

Fig. 4 shows the conformation of 17- $\beta$ Estradiol located on the binding site of RE- $\alpha$ with the amino acid residues involved are LEU391, MET388, LEU387, GLU353, ALA350, LEU346, LEU525, MET343,
MET421 and PHE404. Then the type of interaction that is formed is presented in Table 4.

Table 4. Non-Bond Interactions between 17- $\beta$ Estradiol and Estrogen Alfa Receptor (RE- $\alpha$ ).

\begin{tabular}{|c|c|c|}
\hline Amino Acid Residues & $\begin{array}{c}\text { Distance } \\
(\AA)\end{array}$ & Type of Interaction \\
\hline GLU353 & 2,87 & Hydrogen Bond \\
\hline LEU387 & 2,91 & Hydrogen Bond \\
\hline LEU387 & 3,89 & Hydrophobic \\
\hline ALA350 & 4,10 & Hydrophobic \\
\hline MET421 & 4,38 & Hydrophobic \\
\hline LEU391 & 4,69 & Hydrophobic \\
\hline LEU346 & 4,70 & Hydrophobic \\
\hline PHE404 & 5,02 & Hydrophobic \\
\hline MET388 & 5,03 & Hydrophobic \\
\hline LEU387 & 5,05 & Hydrophobic \\
\hline LEU525 & 5,15 & Hydrophobic \\
\hline LEU346 & 5,20 & Hydrophobic \\
\hline ALA350 & 5,24 & Hydrophobic \\
\hline PHE425 & 5,29 & Hydrophobic \\
\hline MET343 & 5,45 & Hydrophobic \\
\hline
\end{tabular}

Table 4 shows the 17- $\beta$ Estradiol molecular interaction with RE- $\alpha$ in the $5 \AA$ range range. It is predicted that there are 2 hydrogen bonds and 13 hydrophobic interactions (Table 4). The amino acid residues involved in forming conventional hydrogen bonds formed between 17- $\beta$ Estradiol and RE- $\alpha$ are GLU353 with a distance of $2.87 \AA$ and LEU387 with a distance of $2.91 \AA$. Then a hydrophobic interaction involving Pi-Sigma is formed between 17- $\beta$ Estradiol and RE- $\alpha$ with the residue involved LEU387 with a distance of $3.89 \AA$. Interactions involving alkyl groups are ALANIN350, METIONIN421, LEUSIN346, METIONIN388, LEUSIN387, LEUSIN525, LEUSIN346, and METIONIN343 with a spacing of 4.10 $\AA, 4.38 \AA, 4.70 \AA$, $5.03 \AA$, 5.05, respectively $\AA, 5.15 \AA$, $5.20 \AA$, and $5.45 \AA$. Other interactions involving PiAlkyl are PHE404, PHE425, ALA350 and LEU391 with a spacing of $5.02 \AA, 5.29 \AA, 5,24 \AA$ and $4,69 \AA$ respectively.

According to Table 4, 17- $\beta$ Estradiol has more hydrophobic bonds, hydrophobically bound ligands with receptors are predicted to produce loose bonds when competing with ligands that have more hydrogen bonds. In addition, too hydrophobic molecules cause the bond selectivity to target receptors to be reduced [17]. 
Based on the results of the analysis of silico daidzein including compounds that act as Selective Estrogen Receptor Modulators (SERMs) based on affective binding values and interactions, daidzein is predicted to compete and prevent agonist binding between endogenous ligand (17- $\beta$ Estradiol) and RE- $\alpha$ through reversible competitive inhibition and making it more selective against estrogen alpha receptors [18].

\section{Conclusion}

Daidzein memiliki energi afinitas yang sangat rendah yaitu $-9,4 \mathrm{kkal} / \mathrm{mol}$ dibanding dengan dibanding $17-\beta$ estradiol yaitu $-8,9 \mathrm{kkal} / \mathrm{mol}$ sehingga Deidzein berpotensi sebagai modulator selektif reseptor estrogen.

We acknowledge Universitas Islam Negeri Sunan Gunung Djati Bandung. We thank to all participant for their help with filed collection and/or technical support.

\section{References}

1. World Health Organisation. 2014. Indonesia, World Health

[http://www.who.int/cancer/countryOrganisation. profiles/idn en.pdf?ua $=1$ ] [diakses tanggal 23 Oktober 2017].

2. Liliana. Uji In Silico Senyawa Emodin Sebagai Ligan Pada Reseptor Estrogen Alfa. Skripsi. Fakultas Farmasi. Universitas Sanata Dharma. Yogyakarta (2016).

3. Fuhrman B J, Brinton L A, Pfeiffer R M, Xu X, Veenstra T D, Teter B E. Estrogen metabolism and mammographic density in postmenopausal women: A Cross-Sectional Study. Cancer Epidemiol Biomarkers Prev. Vol. 4 (10). 1582 - 1590 (2012).

4. Chien, C.D., Riegel, A., Wellstein, A., Coregulators And Their Role In Selective Estrogen Receptor Modulator Action. Weizmann Institute Of Science. 7. 153-159 (2016).

5. Johan, Aprilini Khaterin. Uji In Silico Senyawa Genistein Sebagai Ligan Pada Reseptor Estrogen Alfa. Skripsi. Fakultas Farmasi. Universitas Sanata Dharma. Yogyakarta (2016).

6. Lee, L.W., Ming, H.C., Hsiang, T.C., dan Peng, H.W. The Role Of Selective Estrogen Receptor Modulators On Breast Cancer: From Tamoxifen To Raloxifene. Taiwan J Obstet Gynecol. 47 (1): 24 31 (2008).

7. Senkus, E., Kyriakides, S., Ohno, S., PenaultLlorca, F., Poortmans, P., Rutgers, E. Primary breast cancer: ESMO Clinical Practice Guidelines for diagnosis, treatment and follow-up. Annals of Oncology. 26 (5): 8-30 (2015).
8. Messina, M., Messina, V. The Role of Soy in Vegetarian Diets. Nutrients. 2: 855 -888 (2010).

9. Choi E.J., dan Kim G.H., Antiproliferative activity of daidzein and genistein may be related to ER $\alpha / \mathrm{c}-$ erbB-2 expression in human breast cancer cells. $\mathrm{Mol}$ Med Rep. 7 : 781-784 (2013).

10. Gatchell, Sara. Isoflavone sources and bioavailability. Independent Project in Biology. (Bachelor Thesis. Department of Food Science, Faculty of Natural Resources and Agricultural Sciences. Sveriges Lantbruksuniveritet. 2016).

11. Wijaya, Eron Tirta. Penapisan Virtual Interaksi Senyawa Fenolik, Alkaloid dan Saponin dengan Reseptor Estrogen Alfa. (Tesis. Sekolah Pasca Sarjana. Institut Pertanian Bogor, 2015).

12. McDonald W., Chie F., Yang Li, Istvan, Ying chen, James A. Fee, C. David Stout, olof E. Ligand Access to the Active Site in Thermus thermophilus ba 3 and Bovine Heart aa 3 cytochrome Oxidases. Biochemistry. 52 (4) : 640-652 (2013)

13. Syahputra, G. Simulasi Docking Senyawa Kurkumin Dan Analognya Sebagai Inhibitor Enzim 12-Lipoksigenase. (Tesis. Sekolah Pascasarjana. Institut Pertanian Bogor, 2014.)

14. Bissantz, Caterina, Gerd Folker, Didier Rognan. Protein-Based Virtual Screening of Chemical Databases. 1. Evaluation of Different Docking/Scoring Combinations. J. Med. Chem. , 43 (25). pp 4759-4767 (2000)

15. Pratama, M.R.F. Studi Docking Molekular Senyawa Turunan Kuinolin Terhadap Reseptor Estrogen Alfa. Jurnal Surya Medika. 2 (1): 1 - 7 (2016).

16. Biovia Discovery Studio. Non-Bond Interaction. 3D Exprience Company. (2015).

17. Rachmania, R.A., Supandi dan Oetari, A.L. InSilico Analysis of Diterpenoid Lactone Compounds of Bitter Herbs (Andrographis paniculata Nees) on Alpha-Glucosidase Receptor as Antidiabetic Type II Agents. Pharmacy. Vol. 12 (2): 210 - 222 (2013).

18. Radharani, M., Madhan, A., Ravi, A., Vered, S., Christopher, BU., and Saed, K. Poten Genistein Derivatives as Inhibitor of Estrogen Receptor Alpha-Positive Breast Cancer. Departemen of Surgery. John Hopkins University School of Medicine. Cancer Research Building. Baltimore MD. USA. Cancer Biologi and Teraphy. 11 (10): 883-892 (2011). 